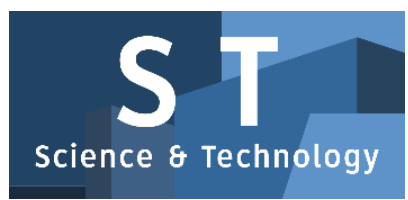

PAPER - OPEN ACCESS

\title{
Implementasi Metode Elemen Hingga Untuk Persoalan Aliran Air Pada Jaringan Pipa
}

\author{
Author \\ : Cici Hayani \\ DOI \\ : 10.32734/st.v1i1.190 \\ Electronic ISSN \\ : 2654-7086 \\ Print ISSN \\ : 2654-7078
}

Volume 1 Issue 1 - 2018 TALENTA Conference Series: Science \& Technology (ST)

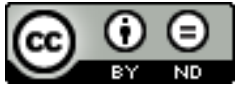

This work is licensed under a Creative Commons Attribution-NoDerivatives 4.0 International License.

Published under licence by TALENTA Publisher, Universitas Sumatera Utara
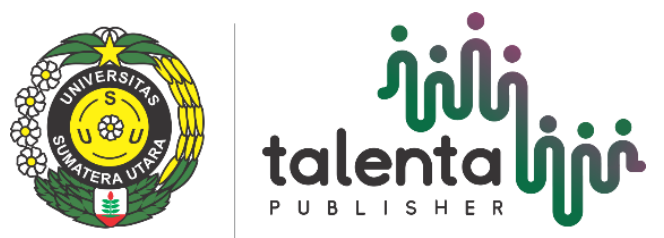


\title{
jijili talentalio TALENTA Conference Series \\ P U B L I S H E R Available online at https://talentaconfseries.usu.ac.id \\ Implementasi Metode Elemen Hingga Untuk Persoalan Aliran Air Pada Jaringan Pipa
}

\author{
Cici Hayani ${ }^{\mathrm{a}^{*}}$, Tulus ${ }^{\mathrm{a}}$, Sawaluddin ${ }^{\mathrm{a}}$
}

Fakultas MIPA, Universitas Sumatera Utara, Medan-20155

cici.hayani@gmail.com ; tulus@usu.ac.id ; sawaluddin@usu.ac.id

\begin{abstract}
Abstrak
Pada zat cair yang mengalir di dalam bidang batas (contohnya pipa) akan terjadi tegangan geser dan gradien kecepatan pada seluruh medan aliran karena adanya kekentalan (viskositas). Penelitian ini bertujuan untuk melihat persoalan aliran air pada jaringan pipa yang diselesaikan dengan mengimplementasikan metode elemen hingga pada persamaan Navier-Stokes yang merupakan persamaan diferensial dasar yang menggambarkan aliran dari fluida Newtonian tak mampu-mampat. Dalam metode elemen hingga, medan aliran dipecah menjadi sekumpulan elemen-elemen fluida kecil (diskritisasi domain). Dalam penelitian ini peneliti menggambarkan aliran air pada bidang dua-dimensi (2D), kemudian dipilih fungsi interpolasi linier untuk elemen 2D, dan menurunkan elemen matriks dan vektor dengan metode Galerkin untuk mendapatkan persamaan Global. Hasil dari penelitian dengan bantuan komputer, memperlihatkan distribusi tekanan dan kecepatan aliran air untuk beberapa variasi bentuk pipa, yaitu pipa I dan pipa T, masing-masing juga dengan variasi posisi inlet/oulet. Hasil simulasi dengan COMSOL menunjukkan, bahwa terdapat hubungan antara tekanan dan kecepatan aliran air, kehilangan tekanan pada salah satu cabang pipa menyebabkan kecepatan aliran air menjadi tidak merata.
\end{abstract}

Kata Kuncis: Navier-Stokes; medan aliran; jaringan pipa; metode elemen hingga; metode Galerkin

\section{Pendahuluan}

Air merupakan salah satu kebutuhan pokok makhluk hidup. Jika air tidak tersedia akan menghambat kehidupan makhluk hidup terutama manusia. Jauhnya sumber air bersih dari konsumen dapat diatasi dengan pembuatan jaringan atau sistem perpipaan. Sistem perpipaan (jaringan pipa) berfungsi mengalirkan zat cair dari suatu tempat ke tempat lain. Sistem perpipaan merupakan bagian paling mahal dari suatu perusahaan distributor air bersih, sehingga harus dibuat perencanaan yang teliti untuk mendapatkan sistem distribusi yang efisien.

Pada zat cair yang mengalir pada bidang batas (contohnya pipa) akan terjadi tegangan geser dan gradien kecepatan pada seluruh medan aliran karena adanya adanya kekentalan (viskositas). Tegangan geser tersebut akan menyebabkan terjadinya kehilangan tenaga selama pengaliran. Jika aliran mengalami kehilangan tenaga pada salah satu cabang pipa, tentunya akan menyebabkan air tidak mengalir secara merata. Beberapa faktor lain yang menyebabkan air tidak terdistribusi secara merata adalah adanya kebocoran pada pipa, pencurian air oleh pihak yang tidak bertanggungjawab, dan sebagainya.

Penelitian ini bertujuan untuk mengetahui bagaimana distribusi tekanan dan kecepatan aliran dalam pipa mendatar (horizontal), pipa tegak (vertikal), dan pipa bercabang dengan implementasi metode elemen hingga. Metode elemen 
hingga adalah metode numerik yang digunakan untuk menyelesaikan permasalahan teknik dan problem matematis suatu gejala phisis [5]. Dalam metode elemen hingga, medan aliran dipecah menjadi sekumpulan elemen-elemen fluida kecil. Analisis jaringan pipa ini cukup rumit dan memerlukan perhitungan yang besar. Oleh karena itu untuk menyelesaikan tugas akhir ini software yang digunakan adalah software COMSOL Multiphysics 4.2a.

\section{Landasan Teori}

\subsection{Metode Elemen Hingga}

Metode Elemen Hingga juga merupakan teknik numerik untuk mencari solusi pendekatan persamaan diferensial parsial (PDP) juga persamaan integral. Pendekatan solusi yang dasar baik itu dengan mengeliminasi persamaan diferensial sepenuhnya (steady state problem), atau mengubah persamaan diferensial parsial menjadi sebuah sistem aproksimasi dari persamaan diferensial biasa, yang lebih erintegrasi secara numerik menggunakan teknik standar seperti Metode Euler, Runge-Kutta, dan lain sebagainya [2].

Ide dasar dalam metode elemen hingga adalah untuk menemukan solusi dari masalah yang rumit dengan menggantinya menjadi masalah yang sederhana [4]. Metode elemen hingga melibatkan pemodelan struktur menggunakan elemen yang saling berhubungan kecil yang disebut elemen-elemen hingga (finite elements). Sebuah fungsi perpindahan terkait dengan setiap elemen hingga. Setiap elemen yang berhubungan terkait, langsung maupun tidak langsung, untuk setiap elemen lain melalui interfaces, termasuk node dan/atau garis batas dan/atau permukaan (surface), [3].

Allaire (1985) menyebutkan langkah-langkah dalam metode elemen hingga adalah sebagai berikut:

1. Merumuskan governing equations (persamaan pengatur) dan kondisi batas,

2. Membagi daerah analisis menjadi elemen-elemen (diskritisasi),

3. Memilih fungsi interpolasi,

4. Menentukan sifat elemen,

5. Merakit/menggabungkan persamaan global,

6. Solusi persamaan global,

7. Verifikasi solusi.

Persamaan dalam metode elemen hingga adalah

$$
[K] \vec{\Phi}=\vec{P}
$$

di mana $[K]$ adalah kumpulan matriks kekakuan (stiffness matrix), (I) ${ }^{\text {ti }}$ adalah vektor perpindahan nodal (nodal displacement), dan $/ 3^{\text {ti }}$ adalah vektor dari gaya nodal (nodal force) untuk struktur lengkap [4].

\section{Pembahasan}

\subsection{Aliran Air}


Zat cair riil didefinisikan sebagai zat yang mempunyai kekentalan. Kekentalan disebabkan karena adanya sifat kohesi antara partikel zat cair. Karena adanya kekentalan zat cair, maka terjadi perbedaan kecepatan partikel pada medan aliran. Zat cair yang berdampingan dengan dinding batas akan diam (kecepatan nol) sedang yang terletak pada suatu jarak tertentu dari dinding akan bergerak. Perubahan kecepatan tersebut merupakan fungsi jarak dari dinding batas. Aliran zat cair riil disebut juga aliran viskos. Untuk aliran viskos, apabila pengaruh kekentalan (viskositas) adalah cukup dominan sehingga zat cair bergerak secara teratur menurut lintasan lurus maka alirannya adalah aliran laminar.

Dalam sejumlah besar masalah aliran fluida (terutama yang dengan cairan viskositas rendah, seperti air dan gas), efek dari viskositas akan menjadi kecil dibandingkan dengan jumlah lainnya, seperti tekanan, gaya inersia, dan medan kekuatan; maka, cairan dapat diperlakukan sebagai fluida inviskos. Masalah khas di mana efek dari viskositas fluida dapat diabaikan adalah aliran melalui lubang, mengalir di atas bendung, mengalir dalam saluran dan saluran pintu masuk, dan mengalir dalam saluran konvergen dan divergen. Dalam masalah aliran fluida, kecepatan fluida dan tekanan fluida ditentukan sebagai fungsi dari koordinat ruang dan waktu. Solusi ini akan sangat sederhana jika viskositas fluida diasumsikan nol.

\subsection{Kondisi Awal dan Batas}

Untuk persoalan aliran air dalam penelitian ini diasumsikan jenis fluida (air) sebagai berikut:

1. Incompressible fluid (fluida tak mampu-mampat, $p$ konstan),

2. Inviscid fluid (fluida nonviskos/tanpa gesekan),

3. Laminar flow (aliran laminar),

4. Air yang mengalir di sepanjang pipa jernih.

Persamaan Navier-Stokes (governing equation)

$$
\begin{gathered}
\rho \frac{\partial u}{\partial t}+\rho(u \cdot \nabla) u=\nabla \cdot\left[-p \boldsymbol{I}+\mu\left(\nabla u+(\nabla u)^{T}\right)\right]+F \\
\rho \nabla \cdot u=0
\end{gathered}
$$

dengan nilai batas (boundary condition)

$$
\begin{aligned}
& \text { Inlet: } p=p_{0},\left[\mu\left(\nabla u+(\nabla u)^{T}\right)\right] n=0 \\
& \text { Outlet: } p=p_{0},\left[\mu\left(\nabla u+(\nabla u)^{T}\right)\right] n=0
\end{aligned}
$$

\subsection{Simulasi Model dengan COMSOL Multiphysic 4.2a}

Untuk model dalam penelitian ini, penulis memodelkan aliran air dalam pipa dua-dimensi (2D); mengambil irisan fluida (air) dalam pipa (bidang 2D). Dengan memberikan paramater dan material yang

terdapat dalam Tabel 1 dan 2, sehingga diperoleh model yang sesuai. 
$\underline{\text { Table 1: Parameter yang digunakan untuk geometri pipa }}$

\begin{tabular}{ccc} 
Nama & Nilai & Keterangan \\
\hline D & $26 \mathrm{~mm}$ & Diameter pipa \\
L & $10 \mathrm{~cm}$ & Panjang Pipa \\
\hline
\end{tabular}

Table 2: material Properties air

Density(Kepadata)

Dynamic Viscosity (Viskositas Dinamik)
$1000 \mathrm{Kg} / \mathrm{m}^{3}$

$1,519 \mathrm{e}-3 \mathrm{~Pa}^{*} \mathrm{~s}$ 
Variasi pipa dalam penelitian ini adalah sebagai berikut:

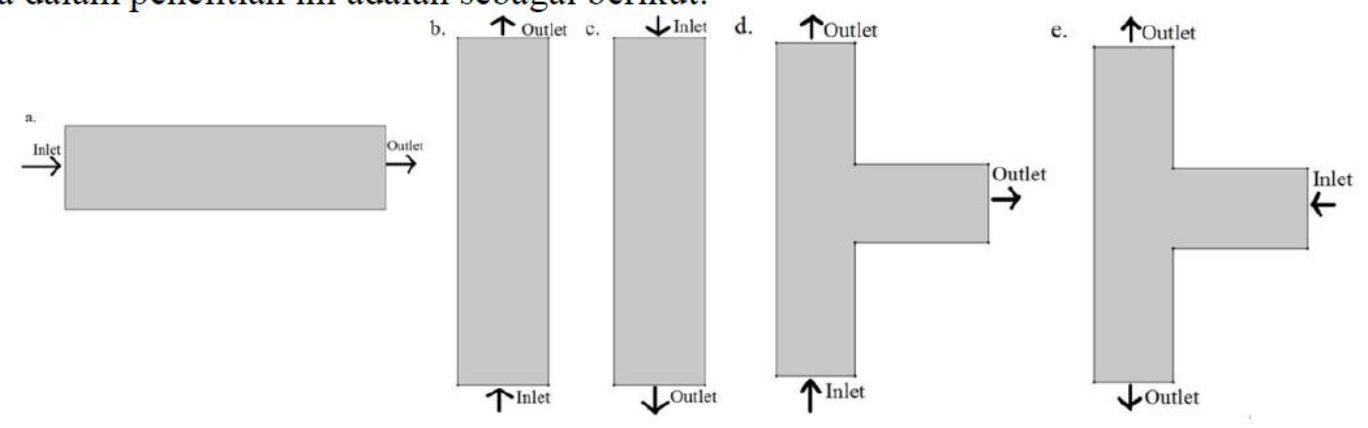

Gambar 1: a. Pipa $\mathrm{I}_{1}$, b. Pipa $\mathrm{I}_{2}$, c. Pipa $\mathrm{I}_{3}$, d. Pipa $\mathrm{T}_{2}$, e. Pipa $\mathrm{T}_{1}$

Berikut ini adalah mesh untuk pipa I dan pipa $\mathrm{T}$ dengan elemen segitiga:
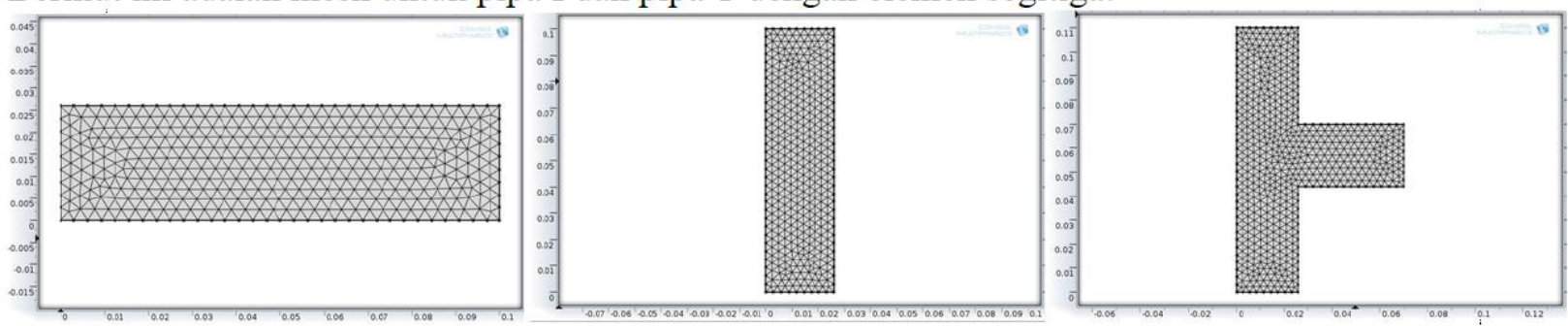

Gambar 2: Mesh

\subsection{Distribusi Tekanan}

Dalam penelitian ini visualisasi model aliran air dalam interval waktu $t=0$ detik sampai dengan $t=3$ detik. Namun, dalam pembahasannya hanya akan di ambil $\mathrm{t}=1$ detik; $\mathrm{t}=1,875$ detik; $\mathrm{t}=2,5$ detik; dan $\mathrm{t}$ $=3$ detik. 


\section{Pipa I}
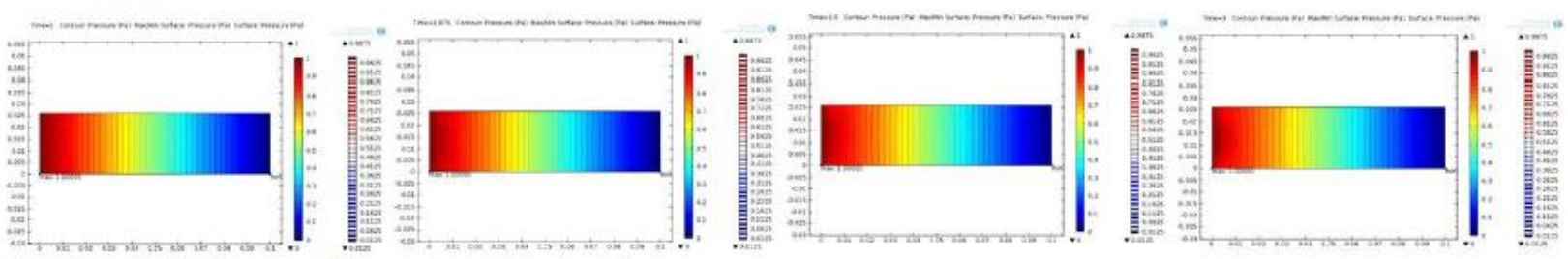

Gambar 3: Tekanan aliran air pada pipa $\mathrm{I}_{1}$
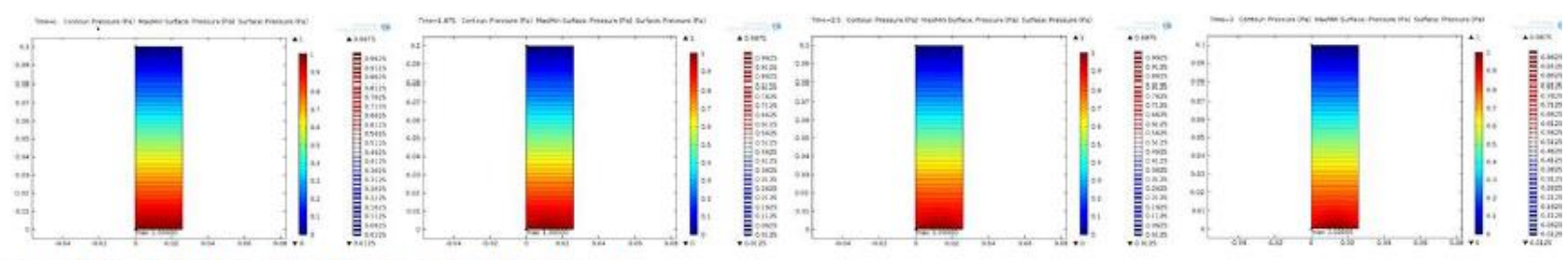

Gambar 4: Tekanan aliran air pada pipa $\mathrm{I}_{2}$
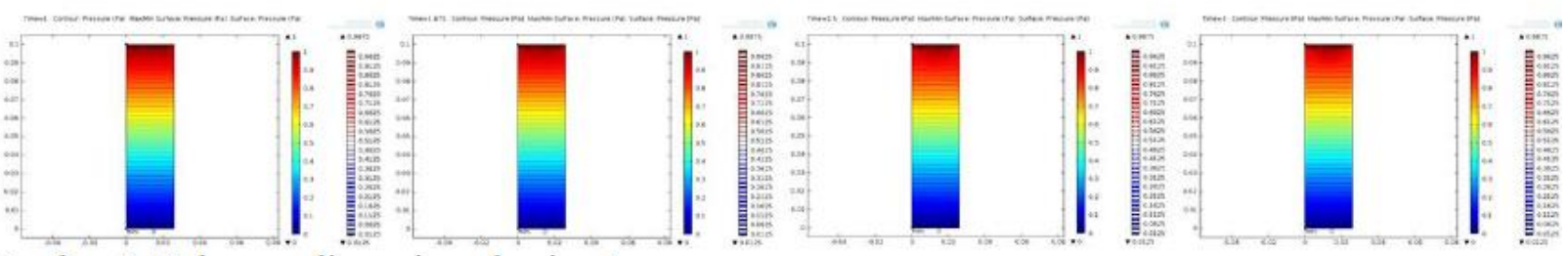

Gambar 5: Tekanan aliran air pada pipa $\mathrm{I}_{3}$

Untuk pipa I (Gambar 3, 4, dan 5), dapat dilihat besarnya tekanan aliran air pada inlet dan outlet pipa. Tekanan aliran air pada pipa I adalah konstan sebesar 1 pada inlet dan 0 pada outlet. Besarnya tekanan pada setiap perubahan posisi/perpindahan (displacement) aliran air sepanjang pipa dapat diperlihatkan dengan kontur tekanan. Semakin merah warnanya, maka tekanan semakin tinggi, sedangkan warna semakin biru menunjukkan besar tekanan yang semakin rendah/berkurang. Hal ini juga berlaku untuk kecepatan aliran air. 
2. Pipa T

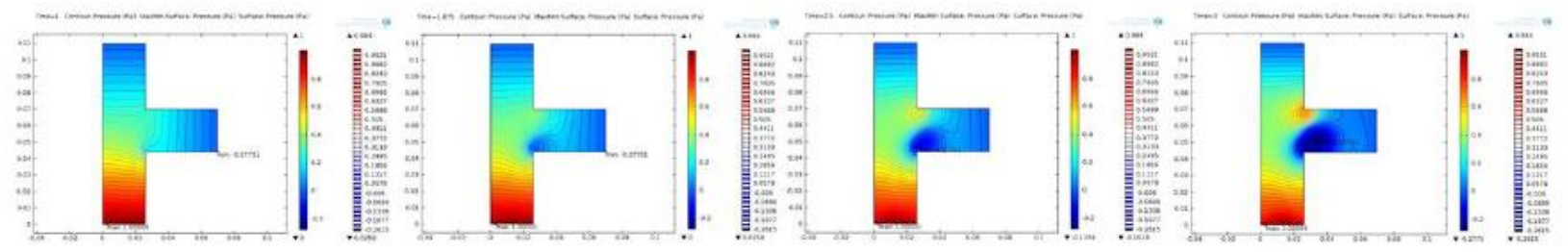

Gambar 6: Tekanan aliran air pada pipa $\mathrm{T}_{1}$
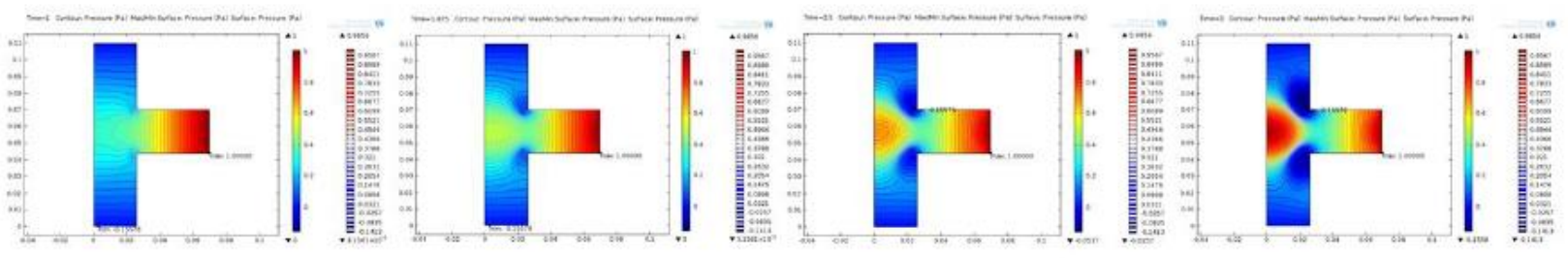

Gambar 7: Tekanan aliran air pada pipa $\mathrm{T}_{1}$

Tekanan tidak tergantung terhadap waktu, namun tekanan tergantung pada kedalaman/posisi pipa.

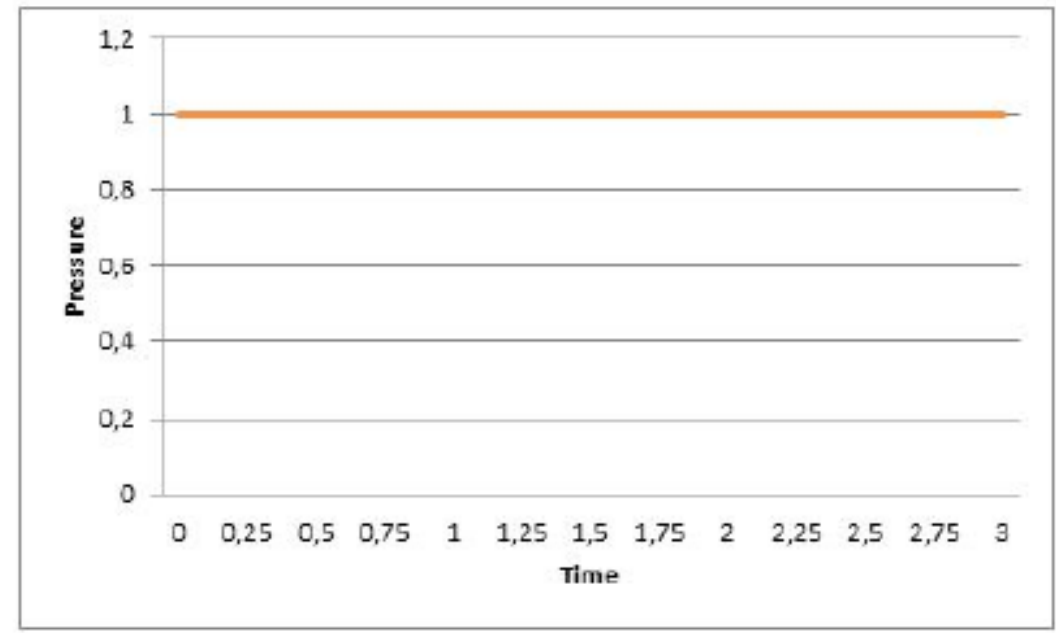

Gambar 8: Grafik distribusi tekanan aliran air pada pipa I dan pipa T

\subsection{Distribusi Kecepatan}

Dengan interval waktu yang sama, akan diperlihatkan distribusi kecepatan aliran air pada pipa, sebagai berikut: 


\section{Pipa I}
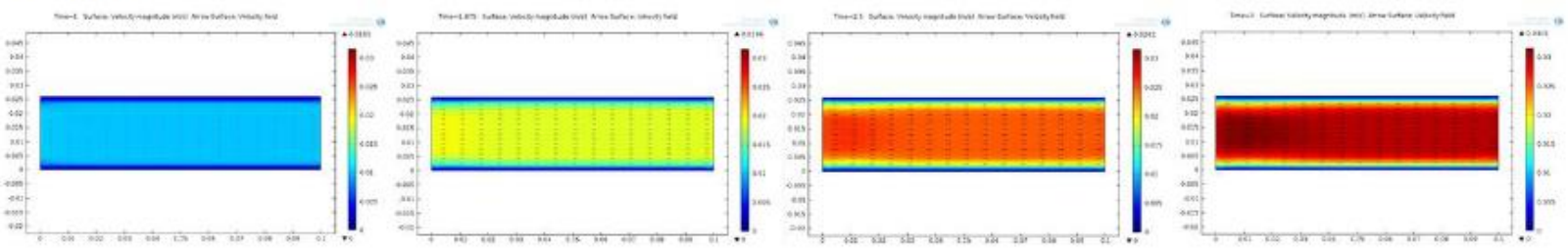

Gambar 9: Kecepatan aliran air pada pipa $\mathrm{I}_{1}$
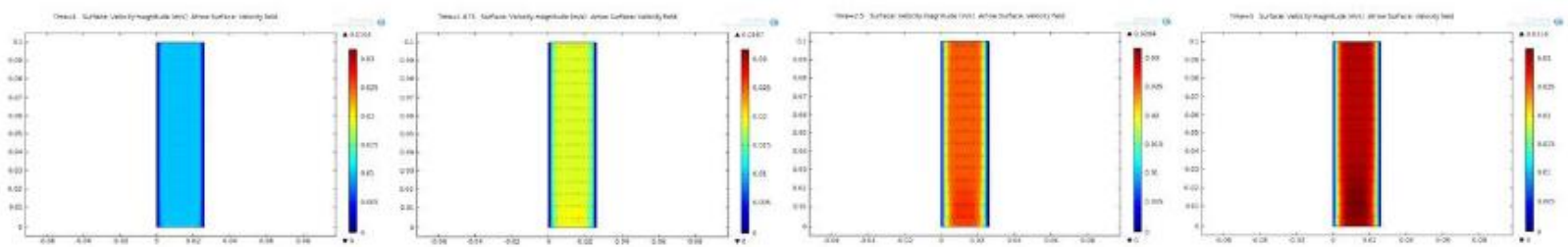

Gambar 10: Kecepatan aliran air pada pipa $\mathrm{I}_{2}$
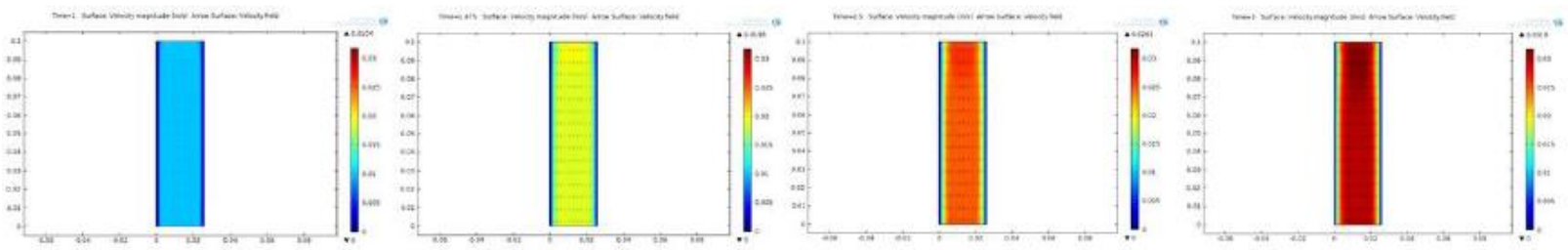

Gambar 11: Kecepatan aliran air pada pipa $\mathrm{I}_{3}$

Untuk pipa I (Gambar 9, 10, dan 11), dapat dilihat kecepatan aliran air pada pipa I meningkat terhadap waktu. Perhatikan bahwa kecepatan lebih tinggi pada pusat pipa dari pada dinding pipa. Hal ini karena kondisi tanpa slip (tanpa gesekan) pada dinding pipa sebagai kondisi batas dan kecepatan menuju garis normal adalah nol. Perbedaan besarnya kecepatan aliran air antara pipa I1, I2, dan I3 terhadap waktu cukup kecil. Kecepatan aliran air pada inlet dan outlet sama untuk pipa I.

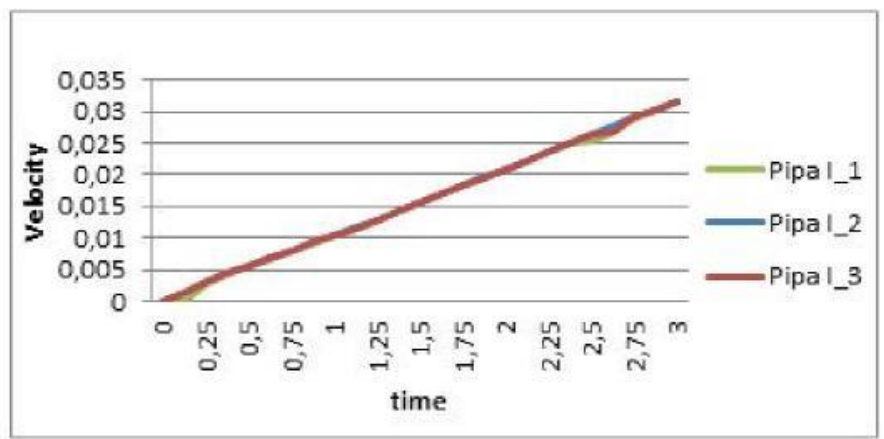

Gambar 12: Grafik

pada pipa I

distribusi kecepatan aliran air 


\section{Pipa T}

Untuk pipa T pada Gambar 13 dan 14, terlihat kecepatan aliran air terbesar pada inlet. Pada pipa T, terdapat penurunan kecepatan aliran air pada cabang pipa.
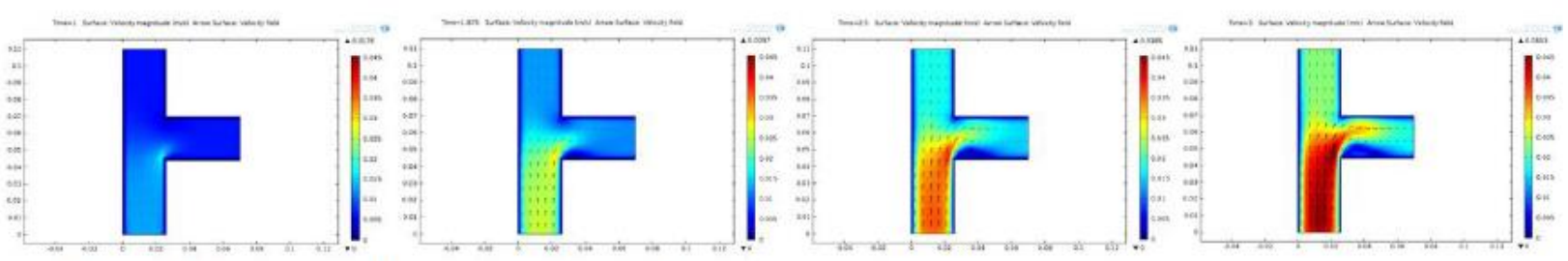

Gambar 13: Kecepatan aliran air pada pipa $\mathrm{T}_{1}$
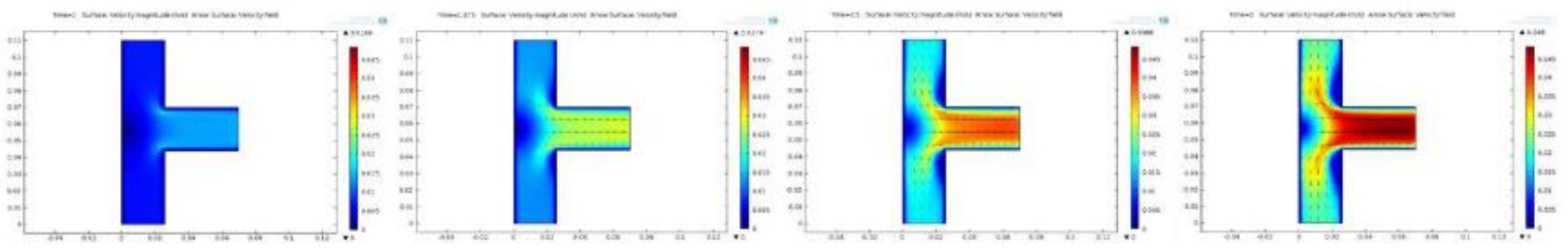

Gambar 14: Kecepatan aliran air pada pipa $\mathrm{T}_{2}$

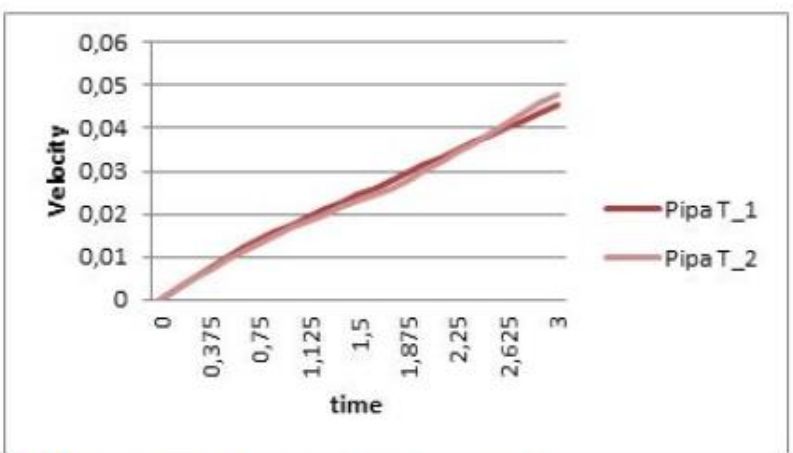

Gambar 15: Grafik distribusi kecepatan aliran air pada pipa $\mathrm{T}$

\section{Kesimpulan}

Dari pembahasan, memperlihatkan bahwa terdapat distribusi tekanan dan kecepatan aliran air pada pipa untuk masing-masing variasi pipa (pipa I dan pipa T) dan masing-masing juga dengan variasi posisi inlet/outlet pada pipa. Dari hasil simulasi dengan COMSOL untuk pipa bercabang (pipa T) dapat disimpulkan bahwa terdapat hubungan antara kecepatan dan tekanan aliran air pada pipa. Kehilangan tekanan pada salah satu cabang pipa menyebabkan kecepatan aliran air menjadi tidak merata. Pada pipa T2, tekanan dan kecepatan aliran air sama/merata ke masing-masing cabang pipa (menuju outlet ), sedangkan pada pipa T1 tekanan dan kecepatan aliran air tidak merata.

\section{Referensi}

[1] Allaire, Paul E. 1985. Basic of the Finite Element Method: Solid Mechanics, Heat Transfer and Fluid Mechanics. Wm. C. Brown. USA. 
[2] Brandenburg, Jenna. and Clemmons, Lashaun. 2012. First edition, Analysis of Numerical Differential Equations and Finite Element Method. College Publishing House. Delhi.

[3] Logan, Daryl L. 2007. Fourth edition, A First Course in the Finite Element Method. Thomson. Canada.

[4] Rao, Singiresu S. 2011. Fifth edition, The Finite Element Method in Engineering. British Library. USA.

[5] Susatio, Yerri. 2004. Dasar-dasar Metode Elemen Hingga. Andi Offset. Yogyakarta.

[6] Triatmodjo, Bambang. 1993. Hidraulika II. Beta Offset. Yogyakarta. 